\author{
JUSTYNA JASIEWICZ \\ Wydział Dziennikarstwa, Informacji i Bibliologii \\ Uniwersytet Warszawski \\ e-mail: justyna.jasiewicz@uw.edu.pl
}

\title{
OBSZARY, PROBLEMY I METODY BADAWCZE LIBRARY AND INFORMATION SCIENCE CZĘŚĆ I
}

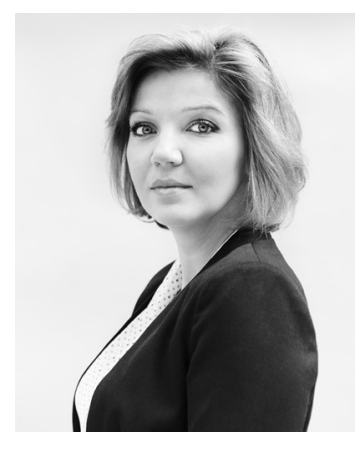
dowych, w tym Fundacji Orange i Fundacji Nowoczesna Polska, w latach 2014-2016 head of research w Centrum Cyfrowym Projekt: Polska.

SŁOWA KLUCZOWE: Bibliologia i informatologia. Library and information science. Obszary badawcze. Metody badawcze. Bibliometria

ABSTRAKT: Teza/cel artykułu - Celem niniejszego badania jest określenie kluczowych obszarów badawczych, które obecnie dominują w dyscyplinie library and information science oraz identyfikacja najczęściej wykorzystywanych metod i technik badawczych. Jest to pierwsza część artykułu otwierającego cykl tekstów poświęconych problematyce metod badawczych stosowanych w obszarze LIS. Metoda - Na potrzeby opracowania niniejszego artykułu przeprowadzono przegląd piśmiennictwa (w pierwszej części) oraz analizę bibliometryczną na podstawie 2190 abstraktów artykułów opublikowanych w najważniejszych czasopismach z obszaru information science (w drugiej części). Wyniki - Wykazano, które zagadnienia i problemy badawcze są obecnie kluczowe dla LIS - zarówno na pod- 
stawie opracowań teoretycznych, jak również pomiarów biblio- i naukometrycznych. Zidentyfikowano najważniejsze metody i techniki badawcze: badania bibliometryczne, big data, analiza literatury. Wykazano rzadsze wykorzystywanie metod badawczych wymagających interakcji z respondentem: wywiadów, eksperymentów, obserwacji oraz triangulacji metodologicznej. Wnioski - Ze względu na dobór czasopism do analizy bibliometrycznej zasadne wydaje się przeprowadzenie w przyszłości analogicznego pomiaru w oparciu o czasopisma z obszaru library science.

\section{WPROWADZENIE}

Przestrzeń informacyjno-komunikacyjna, w której funkcjonuje współczesne społeczeństwo, jest w okresie zmian powodowanych rozwojem technologii cyfrowych i dynamicznie poszerzającymi się zasobami informacji dostępnych na rozmaitych nośnikach. To środowisko cyfrowe w oczywisty sposób wpływa na zachowania poszczególnych jednostek, ale również na dyscypliny badawcze, których celem jest rozpoznawanie zjawisk związanych z przepływem danych i informacji pomiędzy ludźmi, instytucjami czy platformami medialnymi. Szczególnie blisko tych zagadnień jest dyscyplina w polskim nazewnictwie określana jako bibliologia i informatologia, a w nazewnictwie anglojęzycznym: library and information science (LIS). Celem niniejszego artykułu jest określenie, jakie są obecnie kluczowe obszary i problemy tej dyscypliny (część 1) oraz - na tym tle zbadanie, jakie metody i techniki badawcze są najczęściej w niej wykorzystywane (część 2).

Ze względu na cele, badanie zrealizowano w dwóch etapach: w pierwszej kolejności przeprowadzony został przegląd piśmiennictwa, w drugiej zaś badanie bibliometryczne. Podczas kwerendy piśmiennictwa, starano się wybrać do analizy prace przeglądowe - zarówno te o charakterze teoretycznym, jak również oparte na wynikach badań empirycznych (najczęściej bibliometrycznych). Znaczną część literatury wybranej do przeglądu stanowi grupa polskich prac, autorstwa najważniejszych badaczy polskiej bibliologii. W przekonaniu autorki prace te weszły do kanonu polskiej informatologii, w naturalny sposób stanowiąc punkt wyjścia do dalszych rozważań. Drugi etap badania stanowi autorska analiza bibliometryczna, która doprowadziła do określenia, jakie metody i techniki badawcze są najczęściej wykorzystywane przez autorów publikujących w najważniejszych czasopismach dyscypliny.

Choć przedmiotem niniejszego artykułu nie jest badanie historii i ewolucji dyscypliny (Hjørland, 2015; Sosińska-Kalata, 2013), należy w tym miejscu - jedynie dla porządku - przypomnieć, że dyscyplina dzisiaj określana jako informatologia, ma dość burzliwą historię nazewnictwa, szczególnie jeśli weźmie się pod uwagę jej krótka, bo ledwie nieco ponad stuletnia, tradycję. Początkowo określana jako dokumentacja naukowa, później jako infor- 
macja naukowa, w 2010 r. została włączona do wykazu dziedzin i dyscyplin naukowych właśnie jako informatologia, która to nazwa nawiązuje wprost do prac Marii Dembowskiej. Badaczka ta proponowała nazwanie w ten sposób dyscypliny, która „,stanowi jedną z nauk o komunikacji społecznej, do których należą również m.in. bibliotekoznawstwo, nauka o książce, archiwistyka i nauka o masowym komunikowaniu".

Obecne informatologia znajduje się $\mathrm{w}$ grupie nauk humanistycznych, współtworząc bibliologię i informatologię (Woźniak-Kasperek, 2015). Niestety $\mathrm{w}$ rodzimej literaturze przedmiotu nie funkcjonuje powszechnie przyjęta interpretacja łączna bibliologii i informatologii; akcent kładzie się na to, że przedmiotem badań bibliologii jest książka, a informatologii - informacja. Obszary te w praktyce badawczej stanowią więc subdyscypliny, które w znacznym stopniu są rozłączne, o czym będzie mowa w dalszej części tekstu.

Nierozerwalne związki nauki o książce z nauką o informacji podkreślił Krzysztof Migoń, który stwierdził, że rozwój nauk o informacji i komunikacji sprawił, iż wypracowano informacyjne i komunikacyjne modele bibliologii, co z kolei pociągnęło za sobą odejście od tradycyjnej książki jako kluczowego przedmiotu badań i skupiło wysiłki badawcze wokół zagadnień przekazu i odbioru. „Perspektywa informacyjna i komunikacyjna pozwoliła na znaczne wzbogacenie arsenału pojęć bibliologicznych i przyniosła świetne wyniki tak w pracach teoretycznych i empirycznych, jak też historycznych i współczesnych. W niektórych środowiskach traktowano ją za ostateczny "punkt dojścia” w poszukiwaniach modelu badań bibliologicznych" (Migoń, 2007). Zresztą bliskość tych dyscyplin jest uwarunkowana historycznie: w europejskiej tradycji badawczej naukę o informacji zazwyczaj traktuje się jako kontynuację refleksji teoretycznej wyrosłej z XIX-wiecznej działalności bibliograficznej i dokumentacyjnej, związanej z powstawaniem specjalistycznych bibliotek i innych ośrodków dokumentacji. W piśmiennictwie anglojęzycznym związki te są widoczne już na poziomie nazwy dyscypliny, która od lat 90. XX w., dzięki brzmieniu library and information science (lub w układzie inwersyjnym: information and library science, ILS) nawiązuje do swego wywiedzionego z bibliotekoznawstwa rodowodu (Sosińska-Kalata, 2013). Należy wyraźnie podkreślić, że bibliotekoznawstwo nie jest wyszczególnione w polskiej klasyfikacji nauk humanistycznych jako odrębna dyscyplina, co sprawia, że polskoi anglojęzyczne nazwy dyscypliny nie są tożsame znaczeniowo. Jedynym obszarem, który bezspornie można wyróżnić, jest nauka o informacji, czyli informatologia (information science), co w wyraźny sposób wpływa na przesunięcie ciężaru rozważań przedstawionych w niniejszym tekście w kierunku informatologii, choć pozostałe subdyscypliny (czy w przypadku polskiej klasyfikacji: bibliologia, czy anglosaskiej - bibliotekoznawstwo) również będą się pojawiać. 


\section{DEFINICJA NAUKI O INFORMACJI}

Choć Tefko Saracevic uznaje dążenie do ustalenia „właściwej” definicji informatologii za bezcelowe i naiwne, wydaje się, że rozważania prowadzone $\mathrm{w}$ tym tekście należy rozpocząć przynajmniej od próby przyjrzenia się obecnym w literaturze przedmiotu ujęciom tej dyscypliny (Saracevic, 1999). Nakreślenie kierunków rozwoju i obszarów badań dyscypliny nie jest celem artykułu, służy ukazaniu kontekstu badawczego dla piśmiennictwa, które zostało objęte analizą bibliometryczną. Dzięki krótkiej i - celowo - dość ogólnej charakterystyce tych podejść, nakreślone zostanie tło do dalszych rozważań nt. interdyscyplinarnego charakteru nauki o informacji oraz stosowanych w niej obecnie technik i metod badawczych.

Zdaniem M. Dembowskiej u podstaw informatologii leży zainteresowanie procesami komunikacji międzyludzkiej, postrzeganej jako warunek życiowego powodzenia człowieka, podejmowania przez niego racjonalnych decyzji, funkcjonowania struktur społecznych, a nawet egzystencji człowieka. W Słowniku terminologicznym informacji naukowej pod redakcją tej samej badaczki można przeczytać, że informacja naukowa to dziedzina wiedzy obejmująca całokształt zagadnień teoretycznych i praktycznych związanych z działalnością informacyjna, którą rozumie się jako zorganizowana, mającą na celu gromadzenie, opracowywanie i udostępnianie informacji o osiągnięciach nauki, techniki i innych dziedzin życia społecznego (Dembowska, 1979). Dwadzieścia lat później Dembowska w następujący sposób pisała o informatologii: „Nauka o informacji dzieli swoje zainteresowania komunikacją międzyludzką z innymi, zarówno tradycyjnymi, jak i nowoczesnymi dyscyplinami. Ponieważ granice pomiędzy nimi a nauką o informacji nie są jasno wytyczone, możemy pojmować naukę o informacji jako jedną z licznych obecnie dziedzin inter- lub supradyscyplinarnych, które dążą do integracji różnokierunkowych badań odnoszących się do określonych zjawisk i problemów. (...) Szczególną cechą nauki o informacji jest to, że bada ona różnorodne własności informacji i procesów komunikacji nie oddzielnie, $w$ izolacji, ale $w$ ich dynamicznym wzajemnym oddziaływaniu, ukazującym ich wzajemne związki i współzależności. Innymi słowy: podstawowym przedmiotem nauki o informacji jest badanie stanów, własności i oddziaływania informacji we wszelkich jej postaciach oraz badanie różnorodności procesów komunikacji, oddziałujących na istoty ludzkie i podlegających ich oddziaływaniu. Przedmiotem nauki o informacji są również systemy informacyjne - ich struktura, cele, funkcje, własności, stany i działanie"(Dembowska, 1999).

W Słowniku encyklopedycznym informacji, języków i systemów informacyjno-wyszukiwawczych pod redakcją Bożenny Bojar czytamy, że informacja naukowa to dziedzina wiedzy zajmująca się systemami informacyjno-wyszukiwawczymi i ich użytkownikami, aspektami teoretycznymi, projek- 
towaniem i funkcjonowaniem (Bojar, 2002). To ujęcie wyraźnie akcentuje podejście zorientowane na systemy, podczas gdy pierwsze nadal korzeniami sięga do działalności bibliotek i innych ośrodków dokumentacji oraz, pośrednio, ich użytkowników. Różnice w naturalny sposób związane są z rozwojem technologii, który w bezpośredni sposób wpływa na informatologię.

Zdaniem Tefko Saracevica nauka o informacji odznacza się trzema cechami. Przede wszystkim jest ze swej natury interdyscyplinarna. Jest też połączona z rozwojem technologicznym, który wpływa nie tylko na samą dyscyplinę, ale również na inne gałęzie nauki oraz społeczeństwo jako takie, zaś sama informatologia jest technologicznie sterowana (technology-driven). Po trzecie, nauka o informacji w znaczny sposób wpływa, wraz z innymi dyscyplinami, na rozwój społeczeństwa informacyjnego (Saracevic, 1999).

Marcia Bates określiła natomiast naukę o informacji jako metafield (co można przełożyć na język polski jako metadyscyplinę lub, biorąc pod uwagę kontekst, metaperspektywę), podobnie jak dziennikarstwo i pedagogika, przy zachowaniu świadomości różnic metodologicznych i kompetencyjnych, przecinającą „,W poprzek" inne dyscypliny. „All three of the above-named fields deal with distinct parts of the transmission of human knowledge - information science with the storage and retrieval of it in recorded form, education with the teaching and learning of it, and journalism with the discovery and transmission of news. Under these circumstances, such fields cut across all of what we might call "content" disciplines. Art historians focus on the study of art; information scientists, on the other hand, take art information as but one slice of the full range of information content with which we deal" (Bates, 1999).

Jak widać, nawet $\mathrm{w}$ tym krótkim przeglądzie definicji, nie ma wśród badaczy jednomyślności w zakresie postrzegania informatologii jako takiej. Rozmaite podejścia mogą wynikać, jak twierdziła Dembowska, z różnic $\mathrm{w}$ rozumieniu teoretycznych podstaw nauki o informacji. Mówiąc wprost: zależnie od tego, co badacz będzie uznawał za najważniejsze zagadnienie w obszarze nauki o informacji, będziemy obserwować pewne „nachylenie” w jego pracach. Te „nachylenia”, przeanalizowane i skategoryzowane, pozwalają na określenie, z jakiego typu orientacjami badawczymi w polu informatologii mamy do czynienia. $\mathrm{W}$ istocie jest to wyznaczanie pól badawczych dyscypliny, w którym kluczem są zainteresowania badaczy (Dembowska, 1999; Cisek, 2009; Zins 2007).

\section{OBSZARY BADAWCZE INFORMATOLOGII}

Analiza informatologii jako dyscypliny, wraz z przyjętymi podstawami teoretycznymi i wyborami metodologicznymi, nierozerwalnie łączy się z zagadnieniem obszarów badawczych nauki o informacji. O tym, które tren- 
dy w badaniach informatologicznych są dominujące, a tym samym, jakie ujęcia metanaukowe dominują informują prowadzone badania bibliometryczne. Dają one możliwość weryfikacji na materiale źródłowym teoretycznych koncepcji obszarów badawczych informatologii. Niejako na dowód tego można przytoczyć słowa cytowanego już Tefko Saracevica, który podkreślił, że nauka o informacji powinna być określana przez pryzmat podejmowanych problemów, gdyż jej przedmiot - informacja - jest zjawiskiem podstawowym (basic phenomenon), co sprawia, że badać można tylko jego przejawy, a nie samą materię (Saracevic, 1999).

\section{OBSZARY BADAWCZE INFORMATOLOGII W UJĘCIU TEORETYCZNYM}

Zanim zaprezentowane zostaną wyniki wybranych badań bibliometrycznych, poczynione będzie teoretyczne wprowadzenie w tematykę obszarów badawczych nauki o informacji. Analogicznie jak w przypadku przeglądu definicji informatologii, przytoczone zostaną przede wszystkim prace polskich badaczy - taki wybór wynika z przekonania autorki o tym, że wybrane polskie opracowania weszły niejako do kanonu polskiego piśmiennictwa informatologicznego, w związku z czym stanowią naturalny punkt wyjścia do dalszych analiz.

Warto, analogicznie jak w krótkim przeglądzie definicji informatologii, w pierwszej kolejności przytoczyć opracowanie M. Dembowskiej, która wyróżniła główne grupy zagadnień stanowiące przedmiot badań nauki o informacji: (1) działalność dokumentacyjno-informacyjna, rozumianą jako zespół procesów przekazywania informacji naukowej (w tym gromadzenie i opracowanie dokumentów, przechowywanie i wyszukiwanie informacji oraz powielanie i rozpowszechnianie materiałów informacyjnych), (2) dokumenty jako materialną formę przekazywania informacji oraz (3) sposoby i środki przekazywanie informacji naukowej (Dembowska, 1999).

W wydanym na początku XXI w.Słowniku encyklopedycznym informacji, języków i systemów informacyjno-wyszukiwawczych czytamy, że „najważniejsze problemy [informacji naukowej - dop. JJ] to: teoria i projektowanie języków informacyjno-wyszukiwawczych, tworzenie zbiorów wyszukiwawczych systemów informacji dokumentacyjnej - tu przede wszystkim problemy opracowania dokumentacji i informacji faktograficznej, opracowanie strategii wyszukiwawczych, optymalizacja działania systemów i poprawa efektywności systemów informacyjno-wyszukiwawczych, badania potrzeb informacyjnych użytkowników systemów informacyjno-wyszukiwawczych" (Bojar, 2002).

Kilka lat później cytowany już Chaim Zins, w badaniu delfickim poświęcił dużo uwagi zagadnieniu problemów badawczych informatologii. Na tej podstawie zaproponował mapę wiedzy (knowlegde map) dyscypli- 
ny, w której wyróżnił dziesięć hierarchicznie uporządkowanych i logicznie połączonych ze sobą faset, stanowiących podstawowe problemy badawcze informatologii. Są to:

1. Podstawy dyscypliny ( $w$ tym m.in. historia i teoria LIS, epistemologia nauki o informacji, metodologia).

2. Zasoby (w tym m.in. systemy informacyjne, jakość informacji).

3. Pracownicy informacji (w tym m.in. etyka zawodu, kształcenie).

4. Treść (w tym m.in. klasyfikacja i organizacja informacji).

5. Zastosowanie ( $w$ tym m.in. wyszukiwanie informacji i inne praktyczne aspekty korzystania z systemów informacyjnych).

6. Operacje i procesy ( $\mathrm{w}$ tym $\mathrm{m}$.in. aspekty pośredniczenia dostępie do wiedzy: organizacja, przechowywanie, udostępnianie informacji i zbiorów).

7. Technologie (w tym m.in. zagadnienia technologii informacji i jej nośników).

8. Środowiska (w tym m.in. uwarunkowania etniczne i kulturowe korzystania z informacji).

9. Organizacje (w tym m.in. biblioteki, archiwa, 1., 2. i 3. sektor).

10. Użytkownicy (w tym m.in. zachowania informacyjne, potrzeby informacyjne, strategie wyszukiwania informacji) (Zins, 2007).

Z kolei cytowana już Sabina Cisek, w wyniku badania anglojęzycznej literatury naukowej z lat 2001-2007 stwierdziła, że „przedmiotem nauki o informacji były i sa, najogólniej mówiąc, obiekty, procesy, zdarzenia i zjawiska informacyjne w społeczeństwie, w świecie człowieka, widziane w perspektywie pośredniczenia pomiędzy utrwalonymi zasobami informacji a ludźmi, którzy jej potrzebują" (Cisek, 2009). Badaczka ta kilka lat wcześniej opracowała koncepcję kluczowych obszarów badawczych nauki o informacji. W tym ujęciu było ich siedem:

1. Obiekty, procesy i zjawiska informacyjne w społeczeństwie.

2. Komunikowane w społeczeństwie wiedza, informacja i znaczenia.

3. Zjawiska i procesy informacyjne w nauce.

4. Wyszukiwanie informacji.

5. Użytkownik w świecie informacji, traktowany indywidualnie lub w perspektywie społecznej: jego potrzeby, kształcenie, zachowania, uwarunkowania.

6. Nośniki, systemy informacyjne i źródła informacji rozpatrywane z technicznego i organizacyjnego punktu widzenia oraz

7. Teoria informacji, której przedmiotem badania jest informacja jako taka (Cisek, 2002).

Zdaniem Jadwigi Woźniak-Kasperek ,,informatologia bada zasoby, dystrybucję i społeczną użyteczność informacji, jej właściwości i zachowanie, czynniki oddziałujące na proces komunikowania (jest to podpole humanistyczno-społeczne informatologii), a także technologię niezbędną do przetwarzania danych, konstytuujących później informację i wiedzę, do tworzenia i funkcjonowania systemów w celu zapewnienia optymalnej do- 
stępności i zastosowania informacji (pole techniczne, inżynierskie). W kręgu zainteresowań informatologii są również sposoby reprezentacji informacji i wiedzy, wykorzystanie różnych kodów do efektywnego ich przekazywania, przechowywania i wyszukiwania, także urządzenia i metody przetwarzania" (Woźniak-Kasperek, 2015).

Z kolei Mirosław Górny w 2016 r. stwierdził, że obszary badawcze nauki o informacji można sprowadzić do czterech głównych, a każdy z problemów badawczych informatologii jest szczególnym przypadkiem jednej z poniższych kategorii:

1. Odkrywanie cech i właściwości obiektów i procesów informacyjnych.

2. Badanie funkcji obiektów i procesów informacyjnych.

3. Wyjaśnianie mechanizmów procesów informacyjnych i wszelkich procesów mających miejsce w infrastrukturze informacyjnej.

4. Projektowanie i modernizowanie systemów informacyjnych (Górny, 2016).

Zaprezentowane tu zestawienie (zob. Tab. 1), dalece niepełne w perspektywie dynamicznego przyrostu piśmiennictwa z zakresu informatologii, nie ma na celu porównań, ocen czy skłaniania czytelników do dokonywania wyborów pomiędzy zaprezentowanymi ujęciami. Nie byłoby to w zasadzie możliwe: na obszar badawczy dyscypliny wpływ ma szereg czynników (czas, rozwój technologii, postęp prac badawczych, wpływy innych dyscyplin). Różnice powstałe pod wpływem tych czynników są oczywiste. Chodzi więc raczej o zebranie w jednym miejscu różnych perspektyw badawczych i sposobów interpretacji informatologii, jakie zostały zaproponowane w literaturze przedmiotu w ciagu minionych niemal 20 lat.

Obszary badawcze LIS w wybranych publikacjach.

\begin{tabular}{|c|c|c|}
\hline $\begin{array}{c}\text { Rok } \\
\text { publikacji }\end{array}$ & Autor & Obszary badawcze \\
\hline 1 & 2 & 3 \\
\hline 1999 & $\begin{array}{l}\text { Maria } \\
\text { Dembowska }\end{array}$ & $\begin{array}{l}\text { 1. Działalność dokumentacyjno-informacyjna: procesy przekazywania } \\
\text { informacji naukowej (gromadzenie i opracowanie dokumentów, prze- } \\
\text { chowywanie i wyszukiwanie informacji, powielanie i rozpowszech- } \\
\text { nianie materiałów informacyjnych). } \\
\text { 2. Dokumenty jako materialna forma przekazywania informacji. } \\
\text { 3. Sposoby i środki przekazywanie informacji naukowej. }\end{array}$ \\
\hline 2002 & $\begin{array}{l}\text { Bożenna } \\
\text { Bojar }\end{array}$ & $\begin{array}{l}\text { 1. Teoria i projektowanie języków informacyjno-wyszukiwawczych. } \\
\text { 2. Tworzenie zbiorów wyszukiwawczych systemów informacji doku- } \\
\text { mentacyjnej - tu przede wszystkim problemy opracowania doku- } \\
\text { mentacji i informacji faktograficznej. } \\
\text { 3. Opracowanie strategii wyszukiwawczych. } \\
\text { 4. Optymalizacja działania systemów i poprawa efektywności syste- } \\
\text { mów informacyjno-wyszukiwawczych. } \\
\text { 5. Badania potrzeb informacyjnych użytkowników systemów informa- } \\
\text { cyjno-wyszukiwawczych. }\end{array}$ \\
\hline
\end{tabular}




\begin{tabular}{|c|c|c|}
\hline 1 & 2 & 3 \\
\hline 2002 & Sabina Cisek & $\begin{array}{l}\text { 1. Obiekty, procesy i zjawiska informacyjne w społeczeństwie. } \\
\text { 2. Komunikowane w społeczeństwie wiedza, informacja i znaczenia. } \\
\text { 3. Zjawiska i procesy informacyjne w nauce. } \\
\text { 4. Wyszukiwanie informacji. } \\
\text { 5. Użytkownik w świecie informacji, traktowany indywidualnie lub } \\
\text { w perspektywie społecznej: jego potrzeby, kształcenie, zachowania, } \\
\text { uwarunkowania. } \\
\text { 6. Nośniki, systemy informacyjne i źródła informacji rozpatrywane } \\
\text { z technicznego i organizacyjnego puntu widzenia. }\end{array}$ \\
\hline 2007 & Chaim Zins & $\begin{array}{l}\text { 1. Teoria informacji. } \\
\text { 2. Podstawy dyscypliny (w tym m.in. historia i teoria LIS, epistemolo- } \\
\text { gia nauki o informacji, metodologia). } \\
\text { 3. Zasoby (w tym m.in. systemy informacyjne, jakość informacji). } \\
\text { 4. Pracownicy informacji (w tym m.in. etyka zawodu, kształcenie). } \\
\text { 5. Treść (w tym m.in. klasyfikacja i organizacja informacji). } \\
\text { 6. Zastosowanie (w tym m.in. wyszukiwanie informacji inne praktycz- } \\
\text { ne aspekty korzystania z systemów informacyjnych). } \\
\text { 7. Operacje i procesy ( } w \text { tym m.in. aspekty pośredniczenia w dostę- } \\
\text { pie do wiedzy: organizacja, przechowywanie, udostępnianie infor- } \\
\text { macji i zbiorów). } \\
\text { 8. Technologie (w tym m.in. zagadnienia technologii informacji i jej } \\
\text { nośników). } \\
\text { 9. Środowiska (w tym m.in. uwarunkowania etniczne i kulturowe ko- } \\
\text { rzystania z informacji). } \\
\text { 10. Organizacje (w tym m.in. biblioteki, archiwa, 1., 2. i 3. sektor). } \\
\text { 11. Użytkownicy (w tym m.in. zachowania informacyjne, potrzeby in- } \\
\text { formacyjne, strategie wyszukiwania informacji). }\end{array}$ \\
\hline 2015 & $\begin{array}{l}\text { Jadwiga } \\
\text { Woźniak- } \\
\text {-Kasperek }\end{array}$ & $\begin{array}{l}\text { 1. Zasoby, dystrybucja i społeczna użyteczność informacji. } \\
\text { 2. Właściwości i zachowanie informacji. } \\
\text { 3. Czynniki oddziałujące na proces komunikowania informacji. } \\
\text { 4. Technologia niezbędna do przetwarzania danych, konstytuujących } \\
\text { informację i wiedzę, tworzenia i funkcjonowania systemów w celu } \\
\text { zapewnienia optymalnej dostępności i zastosowania informacji. } \\
\text { 5. Sposoby reprezentacji informacji i wiedzy. } \\
\text { 6. Wykorzystanie różnych kodów do efektywnego przekazywania, } \\
\text { przechowywania i wyszukiwania informacji i wiedzy. } \\
\text { 7. Urządzenia i metody przetwarzania informacji i wiedzy. }\end{array}$ \\
\hline 2016 & $\begin{array}{l}\text { Mirosław } \\
\text { Górny }\end{array}$ & $\begin{array}{l}\text { 1. Odkrywanie cech i właściwości obiektów i procesów informacyjnych. } \\
\text { 2. Badanie funkcji obiektów i procesów informacyjnych. } \\
\text { 3. Wyjaśnianie mechanizmów procesów informacyjnych i wszelkich } \\
\text { procesów mających miejsce w informacyjnej infrastrukturze. } \\
\text { 4. Projektowanie i modernizowanie systemów informacyjnych. }\end{array}$ \\
\hline
\end{tabular}

Źródło: oprac. własne.

\section{OBSZARY BADAWCZE INFORMATOLOGII W ŚWIETLE BADAŃ BIBLIOMETRYCZNYCH}

Jak już wspomniano, empiryczną weryfikacją przytoczonych powyżej teoretycznych ujęć obszarów badawczych nauki o informacji są badania bibliometryczne, prowadzone w oparciu o bieżące piśmiennictwo naukowe. Spośród projektów tego typu, mających na celu uchwycenie przemian pola 
badawczego nauki o informacji, na szczególną uwagę zasługują prace zagraniczne, będące efektem badań prowadzonych z wykorzystaniem zaawansowanych metod obliczeniowych, pozwalających na uzyskanie ciekawych wyników. W Polsce, niestety, analizy bibliometryczne są nie tylko rzadsze, ale również prowadzi się je przy wykorzystaniu mniej zaawansowanych metod.

I tak na przykład Frederik Âström stwierdził, że library and information science charakteryzuje się stabilną struktura, a analiza publikacji z 21 najważniejszych czasopism dziedzinowych z lat 1990-2004 pozwoliła mu wyodrębnić dwa pola badawcze: infometrię (infometrics) oraz wyszukiwanie i przetwarzanie informacji (information seeking and retreval) (Åström, 2007).

Z kolei badania przeprowadzone przez Gregorio Gonzáleza-Alcaide i innych, na podstawie analizy bibliometrycznej ponad 11 tys. publikacji zindeksowanych w bazie Library and Information Science Abstracts (LISA) za lata 2004-2005, wskazują na istnienie trzech zasadniczych, choć nieco innych niż w przypadku wyżej wspomnianego badania, głównych pól badawczych LIS. Są to: internet, biblioteki i edukacja. Poza tym zidentyfikowano 12 tematów badawczych, z których aż 11 jest związanych z technologią internetową: sieci, bezpieczeństwo komputerowe, technologie informacyjne, zasoby elektroniczne, publikacje elektroniczne, bibliometria, e-handel, aplikacje komputerowe, medycyna, wyszukiwanie informacji online. Inne problemy, jak społeczne aspekty ICT, prawo autorskie czy informacja biznesowa, cieszą się mniejszym zainteresowaniem. Wyniki tego badania przedstawiono na mapie połączeń poszczególnych tematów (zob. Rys. 1), dzięki czemu widać, które zagadnienia są osiowe, a które peryferyjne. Rezultaty analiz pozwoliły autorom badania stwierdzić, że choć znacząca część prac badawczych poświęcona jest problemom bibliotekoznawstwa i informacji naukowej, w tym praktycznym aspektom ich funkcjonowania, to rozwój technologii cyfrowych sprawił, że to właśnie problematyka ICT jest w sercu dyscypliny (González-Alcaide, Castelló-Cogollos, Navarro-Molina, Aleixandre-Benavent \& Valderrama-Zurián, 2007).

Również Staša Milojević i in. na podstawie maszynowej analizy słów występujących w tytułach ponad 10 tys. artykułów naukowych, opublikowanych w latach 1988-2007 w 16 najważniejszych czasopismach dziedzinowych, stwierdzili, że w obszarze badawczym informatologii można wyróżnić trzy główne gałęzie, których przedmiotami badań są: biblioteki, informacja i nauka. Oczywiście każde z tych pól rozgałęzia się dalej, co widać na opracowanej w wyniku badania mapie kognitywnej pola LIS przedstawionej na rysunku 2. Na mapie też znalazły się takie zagadnienia, jak m.in.: w obszarze bibliotekoznawstwa: biblioteki publiczne, biblioteki akademickie, kompetencje informacyjne, zarządzanie wiedza; w obszarze informacji naukowej: wyszukiwanie informacji, katalogi i bazy danych, wyszukiwanie online; w obszarze bibliometrii i naukometrii: analizy cytowań, współpraca międzynarodowa, wskaźniki itd. Poza trzema głównymi gałę- 


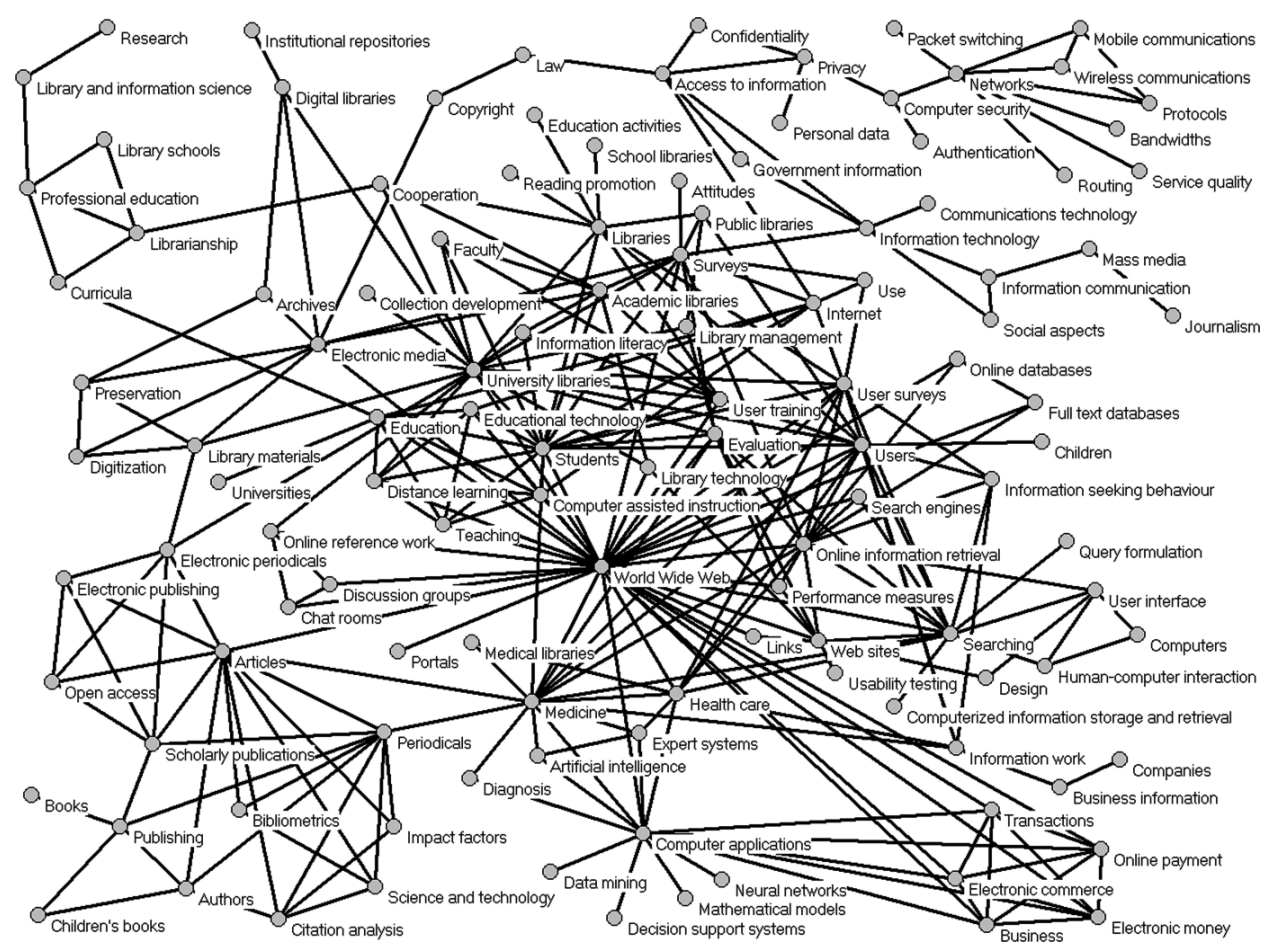

Rys. 1. Mapa połączeń pomiędzy deskryptorami prac indeksowanych w LISA. (González-Alcaide et al., 2007)

ziami zidentyfikowano również dwie kolejne, które zostały określone jako mniej stabilne - są to zachowania informacyjne oraz szkolenie biblioteczne. Autorzy badania przeprowadzili również analizę rozkładu poszczególnych tematów w czasie oraz analizę korelacji badanych czasopism, której wyniki przedstawiono w modelu 3D. Wnioski wysnute z tej części badania wskazują na pewną izolację, w jakiej funkcjonują obszary library and information science. Jest tak m.in. ze względu na wykorzystywane metody badawcze oraz specjalistyczną terminologię, która na szczególne osamotnienie skazuje badanie naukometryczne (Milojević, Sugimoto, Yan, \& Ding, 2011).

Nieco inne są wyniki badań bibliometrycznych, przeprowadzonych na podstawie słów kluczowych 1250 publikacji zamieszczonych w 10 najważniejszych czasopismach dziedzinowych, w latach 2007-2008. Te wskazują na istnienie trzech głównych pól badawczych LIS: technologii informacyjnych, metodologii oraz społecznych aspektów nauki o informacji. Inne zagadnienia, jak wyszukiwanie informacji i jej organizacja oraz problemy związane z edukacją są również obecne $\mathrm{w}$ polu badawczym library and information science, choć w mniejszym stopniu (Aharony, 2012).

W Polsce podobne badania przeprowadziła w ostatnich latach Barbara Sosińska-Kalata, która na podstawie analizy 361 artykułów opublikowanych w czterech czasopismach dziedzinowych w latach 2011-2012 (dla „Journal 


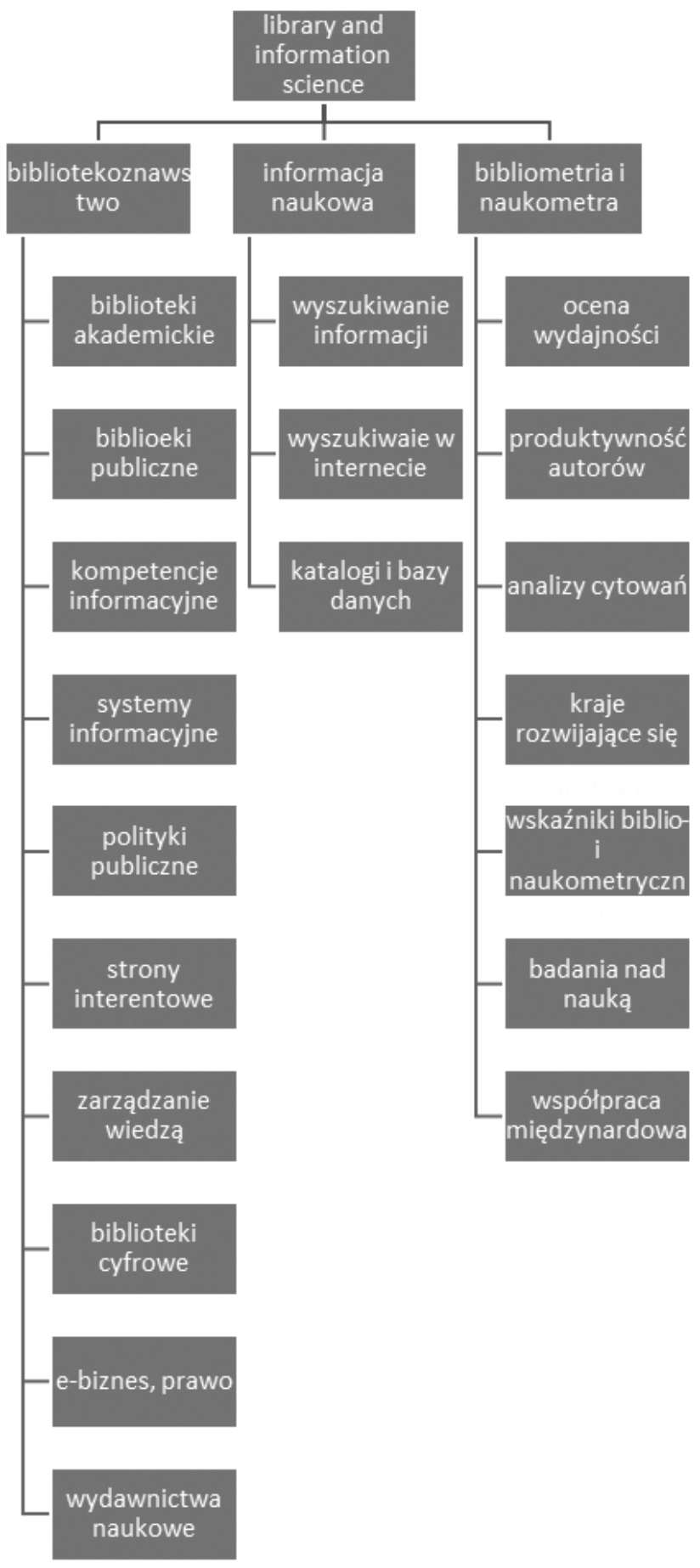

Rys. 2. Obszary badawcze LIS

Źródło: S. Milojević et al. The cognitive structure of library and information science: Analysis of article title words. Journal of the American Society for Information Science and Technology 62.10 (2011): 1950. 
of American Society for Information Science and Technology", , Journal of Information Science" i „Journal of Documentation") oraz 2007-2011 (dla "Annual Review of Information Science and Technology") starała się określić kierunki zmian zachodzących w polu badawczym nauki o informacji. Analiza bibliometryczna pozwoliła autorce stwierdzić, że dominujące w nauce o informacji nurty, czyli technologiczny oraz nakierowany na użytkowników, rozwijają się dość niezależnie od siebie i są uprawiane przez różne środowiska badawcze. Jednocześnie wyniki analiz nie potwierdziły jednoznacznie zwrotu nauki o informacji w kierunku badań społecznych i pojmowania dyscypliny jako nauki zajmującej się zjawiskami informacyjnymi zachodzącymi w świecie społecznym (Sosińska-Kalata, 2013).

Analiza przedstawionych powyżej ujęć teoretycznych obszarów badawczych informatologii i ich empiryczna weryfikacja na podstawie badań bibliometrycznych prowadzą do ciekawych wniosków. Wydaje się przede wszystkim, że ujęcia teoretyczne - nawet te nowsze - nie idą w parze z rozwojem piśmiennictwa naukowego. Być może przyczyn tych rozbieżności należy szukać $\mathrm{w}$ całkowicie innym podejściu metodologicznym - z jednej bowiem strony mamy do czynienia z badaniami ilościowymi (którymi w istocie są badania biblio- i naukometryczne), z drugiej zaś z pracami o charakterze teoretycznym. Wydaje się, że ciekawa byłaby weryfikacja opracowań teoretycznych w perspektywie naukometrii.

\section{INTERDYSCYLINARNOŚĆ LIBRARY AND INFORMATION SCIENCE}

Marcia Bates określiła informatologię jako metafield (Bates, 1999), a Tefko Saracevic wskazał interdyscyplinarność jako jedną z jej trzech głównych cech (Saracevic, 1999). M. Dembowska twierdziła, że w zakresie nauki o informacji można znaleźć elementy czterech podstawowych grup nauk tworzących kamienie węgielne współczesnej wiedzy: nauk humanistycznych, fizycznych, biologicznych i społecznych (Dembowska, 1999). Jadwiga Woźniak-Kasperek w jednej ze swoich prac wskazuje na niejednorodną naturę nauki o informacji, która czerpiąc z matematyki, logiki, lingwistyki, psychologii, socjologii, komunikologii, statystyki, zarządzania czy informatyki, staje się w gruncie rzeczy konglomeratem różnych pól badawczych, które różnią się zarówno pod względem rozpoznania, jak też wagi i trwałości (Woźniak-Kasperek, 2015). Te stwierdzenia wskazywać mogą na wysoce interdyscyplinarny charakter nauki o informacji.

O tym, że interdyscyplinarność takiej nauki jak informatologia jest jej pożądaną i ważną cecha, nie trzeba nikogo przekonywać. Interdyscyplinarność jako taka pozwala na poszerzenie perspektywy badawczej, wzbogacenie argumentacji oraz - co szczególnie ważne w kontekście niniejszych rozważań - zasilenie metodologii i technik badawczych narzędziami z pokrewnych dyscyplin. Wobec tego, analogicznie jak w przypadku badań 
dotyczących obszarów badawczych informatologii, również twierdzenia dotyczące interdyscyplinarności tej dyscypliny zostaną niejako „zderzone" $\mathrm{z}$ wynikami badań bibliometrycznych. Warto $\mathrm{w}$ tym miejscu przypomnieć, że interdyscyplinarność może zachodzić na poziomie cytowania publikacji z innych gałęzi nauki, współpracy badaczy z różnych dyscyplin owocujących wspólnymi publikacjami oraz publikowania prac na zewnątrz macierzystej dyscypliny (Chang \& Huang, 2012).

Analizy bibliometryczne stopnia interdyscyplinarności dyscypliny (poziom cytowań) mogą prowadzić do wniosku, że informatologia jest nauką ograniczoną (oryginalnie: insular field), której wpływ na inne dyscypliny jest niewielki (Tang, 2004). Świadczą o tym chociażby wyniki badań sieci powiązań pomiędzy dyscyplinami, wyrażone w liczbie cytowań publikacji spoza LIS. Badanie dotyczące tego właśnie problemu, którego autorami są Mu-Hsuan Huang oraz Yu-Wei Chang, dowodzi przede wszystkim, że bibliotekoznawstwo i informacja naukowa są obszarami rozłącznymi, a ich reprezentanci korzystają głównie z prac stworzonych w swoich obszarach. Różnice pomiędzy library science i information science wyrażają się również $\mathrm{w}$ tym, do jakich dyscyplin sięgają reprezentujący je badacze. I tak, bibliotekoznawcy są skłonni sięgać po prace z zakresu pedagogiki, zarządzania, socjologii, psychologii, podczas gdy badacze zajmujący się informacją chętniej korzystają z prac z zakresu nauk ogólnych i ścisłych, informatyki, medycyny. Badania przeprowadzone na piśmiennictwie fachowym $z$ lat 1978-2007 wykazały, że stopień interdyscyplinarności wzrastał w czasie, co może prowadzić do przypuszczenia o dojrzewaniu wewnętrznym dyscypliny i gotowości do sięgania po zewnętrzne koncepcje. Warto jednak pamiętać, że badacze z obu gałęzi LIS korzystają przede wszystkim z publikacji powstałych wewnątrz dyscypliny, przy czym wskaźnik ten jest wyższy wśród bibliotekoznawców niż wśród specjalistów nauki o informacji (Huang \& Chang, 2012). Może to wskazywać, że zarówno cała dyscyplina, jak i jej podpola w praktyce są przynajmniej w pewnym stopniu „wsobne”.

Jeśli chodzi o współpracę pomiędzy dyscyplinami (poziom 2), jest ona jeszcze mniej zaawansowana, co może prowadzić do wniosku, że łatwiej jest cytować prace z innych dyscyplin, niż nawiązać współpracę z badaczem spoza własnego pola (Chang \& Huang, 2012). Wydaje się więc, że choć nauka o informacji przyciągać może badaczy spoza jej zasadniczego pola, to siła tego procesu jest paradoksalnie raczej odśrodkowa, co może skutkować „wypływaniem” pewnych tematów na zewnątrz dyscypliny. Mogą na to wskazywać choćby wyniki badań bibliometrycznych przeprowadzonych w oparciu o dysertacje zindeksowane w bazie ProQuest. Jak się okazało, tylko jedna trzecia prac opatrzonych jednym lub obydwoma z deskryptorów dziedzinowych "library science" i ,information science” została opracowana w ośrodkach akademickich LIS. Ciekawe, że prace powstałe w tych ośrodkach dotyczyły przede wszystkim problematyki użytkowników in- 
formacji, a pozostałe - przygotowane na wydziałach zarządzania, informatyki, pedagogiki lub komunikacji - były zogniskowane wokół problemów technologii informacyjnych, gospodarki informacyjnej oraz zarządzania informacją. Autorka badania konkluduje następująco: "Topics related to the study of information that are more closely associated with information technology, information systems, the management of information and knowledge, the value of information and even topics associated with community information such as medical information, were 'taken over' by researchers from different fields, headed by business administration, computer science, education and communication" (Prebor, 2010).

\section{PODSUMOWANIE CZĘŚCI I}

Celem niniejszego badania jest określenie, jakie są główne obszary badawcze oraz najważniejsze problemy nauki o informacji. Analiza literatury przedmiotu wykazała, że istnieją pewne rozbieżności pomiędzy podejściami teoretycznymi a wynikami badań bibliometrycznych w odniesieniu do poszczególnych zagadnień. I tak na przykład wykazano, że pomimo definiowania nauki o informacji jako dyscypliny wysoce interdyscyplinarnej, w rzeczywistości jest ona raczej wsobna, zamknięta $\mathrm{w}$ swoich subdyscyplinach, które stanowią podstawowe źródło inspiracji teoretycznych oraz odniesień literaturowych. Również w zakresie podejmowanych problemów badawczych widać pewne rozbieżności - badania naukometryczne prowadziły do wyodrębnienia zazwyczaj kilku (dwóch lub trzech) kluczowych problemów, na których skupiają się badacze. Ujęcia teoretyczne, zapewne ze względu na swój generyczny charakter, są na innym - wydaje się, że wyższym, meta - poziomie.

Celem drugiej części badania, jak już wspomniano, jest określenie, jakie są najważniejszych metody i techniki badawcze stosowane w obszarze library and information science.

\section{BIBLIOGRAFIA}

Aharony, Noa (2012). Library and Information Science research areas: A content analysis of articles from the top 10 journals 2007-8. Journal of Librarianship and Information Science, 44(1), pp. 27-35. https://doi.org/10.1177/0961000611424819.

Åström, Fredrik (2007). Changes in the LIS research front: Time-sliced cocitation analyses of LIS journal articles, 1990-2004. Journal of the American Society for Information Science and Technology, 58(7), pp. 947-957. https://doi.org/DOI: 10.1002/asi.20567.

Bates, Marcia J. (1999). The invisible substrate of information science. Journal of the American Society for Information Science, 50(12), pp. 1043-1050. https://doi.org/10.1002/(SICI)1097-4571(1999)50:12<1043::AID-ASI1>3.3.CO;2-O.

Bojar, Bożenna (2002). Słownik encyklopedyczny informacji, języków i systemów informacyjno-wyszukiwawczycho Title. (B. Bojar, Ed.). Warszawa: Wydaw. SBP. 
Chang, Yu Wei, \& Huang, Mu Hsuan (2012). A study of the evolution of interdisciplinarity in library and information science: Using three bibliometric methods. Journal of the American Society for Information Science and Technology, 63(1), pp. 22-33. https://doi.org/DOI: 10.1002/asi.21649.

Cisek, Sabina (2002). Filozoficzne aspekty informacji naukowej. Kraków.

Cisek, Sabina (2009). Nauka o informacji na świecie w XXI wieku: badania metanaukowe. Od Książki Dawnej Do Biblioteki Wirtualnej, (1), s. 47-56. Retrieved from http://eprints.rclis. org/11098/1/Cisek_in_na_swiecie_eng.pdf.

Dembowska, Maria (Ed.). (1979). Słownik terminologiczny informacji naukowej. Wrocław: Zakład Narodowy im. Ossolińskich.

Dembowska, Maria (1999). Informacja naukowa jako dyscyplina naukowa. W: M. Dembowska (Ed.), Bibliologia, bibliografia, bibliotekoznawstwo, informacja naukowa. Wybór prac. Warszawa, s. 164-178.

González-Alcaide, Gregorio; Castelló-Cogollos, Lourdes; Navarro-Molina, Carolina; Aleixandre-Benavent, Rafael; Valderrama-Zurián, Carlos Juan (2007). Library and Information Science Research Areas: Analysis of Journal Articles in Lisa. Journal of the American Society for Information Science and Technology, 59(1), pp. 150-154. https://doi.org/DOI: 10.1002/asi.20720.

Górny, Mirosław (2016). Nauka o informacji jako dyscyplina naukowa. W: W. Babik (Ed.), Nauka o informacji. Warszawa, s. 23-40.

Hjørland, Birger (2015). Theoretical development of information science: A brief history.

Huang, M. H.; Chang, Y.W. (2012). A comparative study of interdisciplinary changes between information science and library science. Scientometrics, 91(3), pp. 789-803. https://doi. org/10.1007/s11192-012-0619-7.

Migoń, Krzysztof (2007). Bibliologia wśród innych nauk. Koncepcje, realizacje, perspektywy. W: D. Kuźmina (Ed.), Bibliologia: problemy badawcze nauk humanistycznych. Warszawa, s. 13-24.

Milojević, Staša; Sugimoto, Cassidy R.; Yan, Erjia; Ding, Ying (2011). The Cognitive Structure of Library and Information Science: Analysis of Article Title Words. Journal of the American Society for Information Science and Technology, 62(10), pp. 1933-1953. https://doi.org/DOI: 10.1002/asi.21602.

Prebor, Gila (2010). Analysis of the interdisciplinary nature of library and information science. Journal of Librarianship and Information Science, 42(4), pp. 256-267. https://doi. org/10.1177/0961000610380820.

Saracevic, Tefko (1999). Information science. Journal of the American Society for Information Science, 50(12), p. 1051. https://doi.org/10.1002/(SICI)1097-4571(1999)50:12\%3C1051::AID-ASI2\%3E3.0.CO;2-Z.

Sosińska-Kalata, Barbara (2013). Obszary badań współczesnej informatologii (nauki o informacji). Zagadnienia Informacji Naukowej, 51(2), s. 9-41.

Tang, Rong (2004). Evolution of the interdisciplinary characteristics of information and library science. In: J. B. Bryans. (Ed.), Asist 2004: Proceedings of the 67th AsisET Annual Meeting, Vol 41, 2004: Managing and Enhancing Information: Cultures and Conflicts. J (pp. 41-54).

Woźniak-Kasperek, Jadwiga (2015). Z głównych problemów samoświadomości informatologii. W: E. Gondek (Ed.), Teoretyczne zagadnienia bibliologii i informatologii. Studia i szkice. Katowice, s. 139-157.

Zins, Chaim (2007). Knowledge Map of Information Science. Journal of the American Society for Information Science and Technology, 58(4), pp. 526-535.

Artykut w wersji poprawionej wptynat do Redakcji 24 sierpnia 2017 r. 
JUSTYNA JASIEWICZ

Faculty of Journalism, Information and Book Studies

University of Warsaw

e-mail: justyna.jasiewicz@uw.edu.pl

\title{
AREAS, ISSUES AND RESEARCH METHODS IN LIBRARY AND INFORMATION SCIENCE. PART I
}

KEYWORDS: Book and information studies. Library and information science. Research areas. Research methods. Bibliometrics

\begin{abstract}
Thesis/Objective - The purpose of this study is to identify key research areas in library and information science (LIS) and the most frequently used research methods and techniques. This is the first part of the article which introduces a series of papers dedicated to LIS research methods. Research method - For the purposes of this paper, the author prepared a literature review (first part) and bibliometric analysis of 2190 abstracts of articles published in leading journals in the field of information science (second part). Results The issues and research problems crucial for LIS were identified, based both on theoretical studies and bibliometric and scientific measurements. The most important research methods and techniques were discussed: bibliometrics, big data, literature analysis. Some rare use of research methods involving interactions with respondents was reported: interviews, experiments, observations and methodological triangulation. Conclusions - Taking into consideration the selection of journals for bibliometric analysis, it appears justified to perform analogous research on journals in the field of library science in the future.
\end{abstract}

